\title{
A Review of Diesel Engine Acoustics
}

\section{Sunny Narayan}

Phd Candidate,Mechancial Engineeirng Department, University Of Roma Tre
Noise emitted from diesel engines can be modeled with help of coherence plots which uses single output multiple input method. Sources of noise in diesel engines can be identified and comparisons can be made with spectrum of in cylinder pressure before and after the removal of various sources to identify the effects of sources. Earlier works of Priede has resulted in better understanding of noise components of diesel engines[1]. The objective of this work is to use coherence models for study of diesel engine acoustics phenomenon.

Keywords: Noise,Vibrations,Engine Acoustics.

\section{INTRODUCTION}

A MISO model is shown in figure no 1 where $\mathrm{X} 1, \mathrm{X} 2, \mathrm{X} 3$ etc. are various inputs which are correlated to a single output $\mathrm{Y}(\mathrm{t})[2]$.Goff was first to use this model for source identification of noise in engines[3].In this model $\mathrm{Z}(\mathrm{t})$ is un correlated back ground noise.

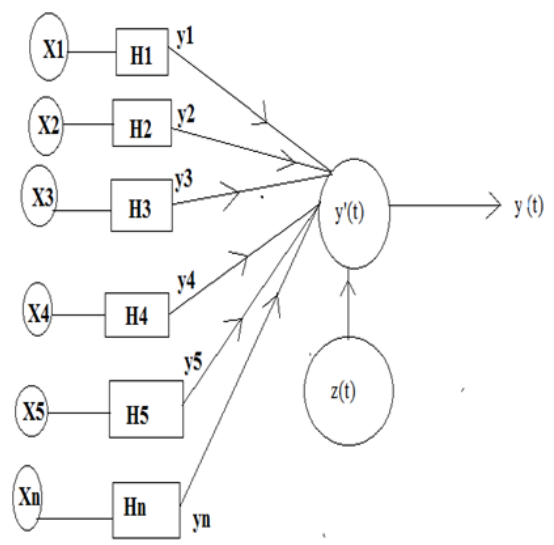

Figure 1-Engine MISO model[2]

In frequency domain the Fourier transformation of output $\mathrm{Y}^{\prime}(\mathrm{f})$ and input $\mathrm{X}(\mathrm{f})$ are related by relationship:

$$
Y^{\prime}(f)=H(f) \cdot X(f)
$$

The transfer function $\mathrm{H}(\mathrm{f})$ between input and output signals given by relationship:

$$
H(f)=S_{x y^{\prime}}(f) / S_{x x}(f)
$$

Where $S_{x y}$ (f) and $S_{x x}$ (f) are cross spectral density and auto spectral density functions defined by following relationships :

$$
\begin{gathered}
S_{x y}(f)=\frac{1}{T}\left[X^{*}(f) \cdot Y(f)\right] \\
S_{x X}=\frac{X^{\prime}(f) X(f)}{\mathrm{T}}
\end{gathered}
$$

Received: November 2013, Accepted: February 2014

Correspondence to: Sunny Narayan

Faculty of Mechanical Engineering,

University Of Roma

E-mail: rarekv@gmail.com

doi:10.5937/fmet1402150N

(C) Faculty of Mechanical Engineering, Belgrade. All rights reserved
The final output function $y(t)$ is sum of uncorrelated noise $z(t)$ and $y^{\prime}(t)$ equation 2 can be written as :

$$
\begin{aligned}
S_{x y}(f) & =\frac{X^{\prime}(f)\left[Z(f)+\mathrm{Y}^{\prime}(f)\right]}{\mathrm{T}} \\
& =S_{X z}(f)+S_{x y}(f)
\end{aligned}
$$

As $z(t)$ is un correlated with $\mathrm{x}(t)$ the term $S_{x z}$ tends to zero it can be inferred that :

$$
S_{x y}(f)=S_{x y^{\prime}}(f)
$$

Hence transfer function gets modified as:

$$
H(f)=\frac{S_{x y}(f)}{S_{x x}(f)}
$$

The coherence function between input function $X$ and output $\mathrm{Y}$ is given by relationship

$$
\gamma^{2}(f)=\frac{S_{x y}(f)}{S_{x x}(f) S_{x y}(f)}
$$

This function denotes how well the mean square value of output function is related to the input functions with value lying between 0 and 1 . As evident from the figure no 1, the output can be expressed as sum of individual outputs and external disturbances. i.e.

$$
\begin{gathered}
y^{\prime}(t)=y(t)+z(t) \\
y^{\prime}(t)=\sum_{i=1}^{n} y_{i}(t)+z(t)
\end{gathered}
$$

Taking Fourier transformations on both sides and multiplying by respective complex conjugate we have:

$$
S_{y y}(f)=\sum_{i=1}^{n} \sum_{r=1}^{n} \mathrm{H}_{i} \mathrm{H}_{r}+\boldsymbol{S}_{z z}(f)
$$

Croker has done modelling experiments of diesel engines using coherence functions[4]. Srivastava has used correlation functions for noise source identification[5].Wang used the above model for localiztion of sources of noise emitted from 3 Loud speakers [6]. 


\section{EXPERIMENTAL TESTS}

Experiments were conducted on a dual cylinder lombardini LDW442CRS common rail direct injection test rig having specifications as presented in table no 1 .

\section{TABLE 1-SPECIFICATIONS OF ENGINE}

\begin{tabular}{|c|c|}
\hline Components & Rating values \\
\hline Bore & $60.6 \mathrm{~mm}$ \\
\hline Stroke & $68 \mathrm{~mm}$ \\
\hline Displacement & $440 \mathrm{~cm}^{3}$ \\
\hline Rated Torque & $\begin{array}{c}25 \mathrm{~N}-\mathrm{m} @ 2000 \\
\text { RPM }\end{array}$ \\
\hline Rated Power & $\begin{array}{c}8.5 \mathrm{Kw} @ 4400 \\
\mathrm{RPM}\end{array}$ \\
\hline Compression & $20: 1$ \\
\hline
\end{tabular}

\section{TABLE 2 -EXPERIMENTAL DATA ACQUIRED}

\begin{tabular}{|c|c|c|c|}
\hline Case & Load & RPM & $\mathrm{P}_{\text {rail }}$ (Bar) \\
\hline B1 & $50 \%$ & 1600 & 508 \\
\hline B2 & $100 \%$ & 1600 & 714 \\
\hline B3 & $0 \%$ & 1600 & - \\
\hline B4 & $50 \%$ & 2000 & 515 \\
\hline B5 & $100 \%$ & 2000 & 710 \\
\hline B6 & $0 \%$ & 2000 & - \\
\hline
\end{tabular}

TABLE 3 -INJECTION PARAMETERS

\begin{tabular}{|c|c|c|c|c|}
\hline Case & $\begin{array}{c}\mathrm{Q}_{\text {pre }} \\
3 \\
(\mathrm{~mm} / \text { stroke) }\end{array}$ & $\begin{array}{c}\mathrm{Q}_{\text {MAIN }} \\
3 \\
(\mathrm{~mm} / \text { stroke) }\end{array}$ & $\begin{array}{c}\text { SOI pre } \\
\text { (DEGREE Before } \\
\text { TDC) }\end{array}$ & $\begin{array}{c}\text { SOI MAIN } \\
\text { (DEGREE Before TDC) }\end{array}$ \\
\hline B1 & 1 & 6.3 & $19.9^{\circ}$ & $5.09^{\circ}$ \\
\hline B2 & 1 & 13.9 & $14.6^{\circ}$ & $6.29^{\circ}$ \\
\hline B3 & - & - & - & - \\
\hline B4 & 1 & 6.6 & $22.5^{\circ}$ & $5.68^{\circ}$ \\
\hline B5 & 1 & 13.8 & $16.5^{\circ}$ & $6.29^{\circ}$ \\
\hline B6 & - & - & - & - \\
\hline
\end{tabular}

A fully opened electronic control unit connected to computer was used to manage the injection system with aim to control operational parameters. The engine was couled with an a synchronous motor of SIEMENS 1PH7 make thus allowing to control speed and load.A Bruel and Kjaer free field microphone of 4939 type with a 2670 type preamplifier was used to obtain acosutic data.This engine test rig has a piezo electric type Kistler 6056A make pressure transducer for in cylinder pressure measurements and an optical crank angle encoder of AVL 364C make for detection of TDC position as well as engine speed. The given system can do maximum of 2 injections per cycle. All sigals were simulatneously acquired by NI boards of 6110 type(for analog type)\& 6533 type(for optical encoder signals) using LabVIEW 10 software.During the tests the sampling ratye was varied in order to guarantee a resolution of $0.25^{\circ} \mathrm{CAD}$. The engine was operated at speeds of 1600 RPM and 2000 RPM under various loaded and motored conditions as seen from Table no $2 \& 3$.

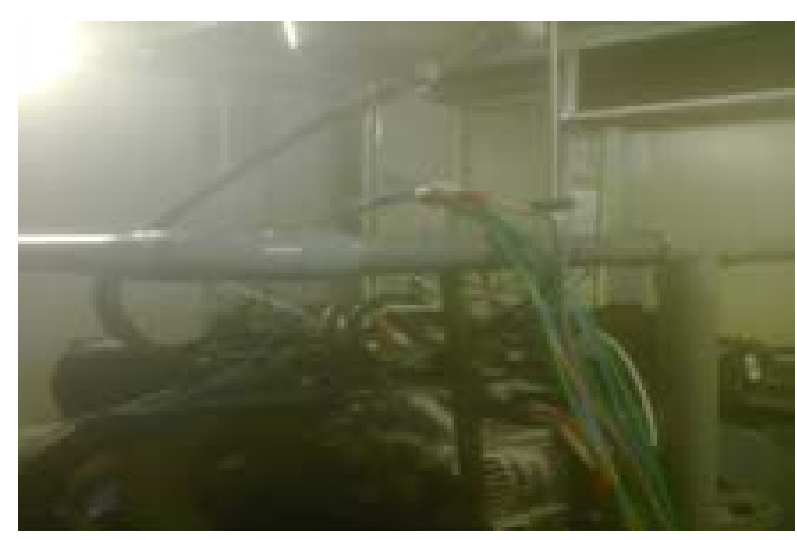

Figure 2-Test Rig Showing Micro phone

\section{RESULTS AND DISCUSSIONS}

Figure 3 shows the variations of raw voltage signals obtained from amplifer for a single cycle of diesel engine with crank angles for various testing conditions.

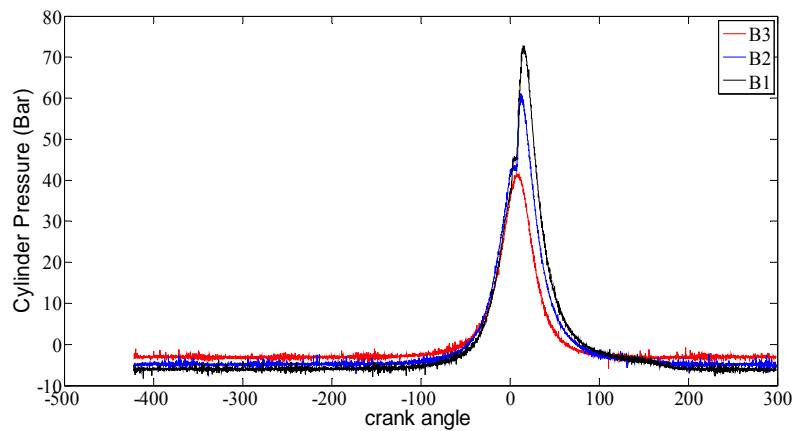

Figure 3-In Cylinder Pressure Trace for various testing conditions(1600RPM)

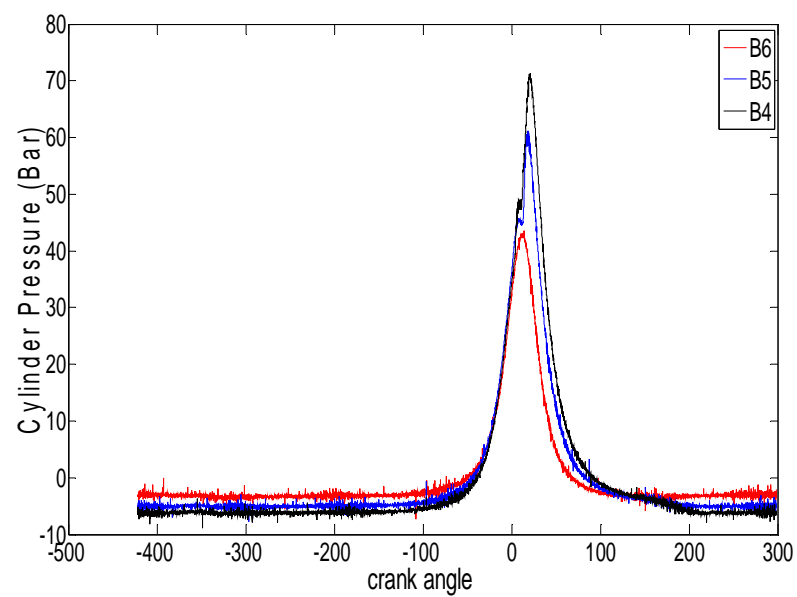

Figure 4-In Cylinder Pressure Trace for various testing conditions(2000RPM)

It can be observed that depending upon engine speed/load condition, the intensity of maximum pressure and its location on crank angle domain changes. The data was converted from crank angle domain into time domain using relevant sampling rate \& then pressure spectrum was plotted using FFT analysis.Figure 4 shows such plot. The signals acquired were filtered to avoid aliasing. The peak value of spectrum was observed to at a frequency of $316 \mathrm{KHz}$. The Cylinder pressure spectrum was found to be load and speed dependent. 


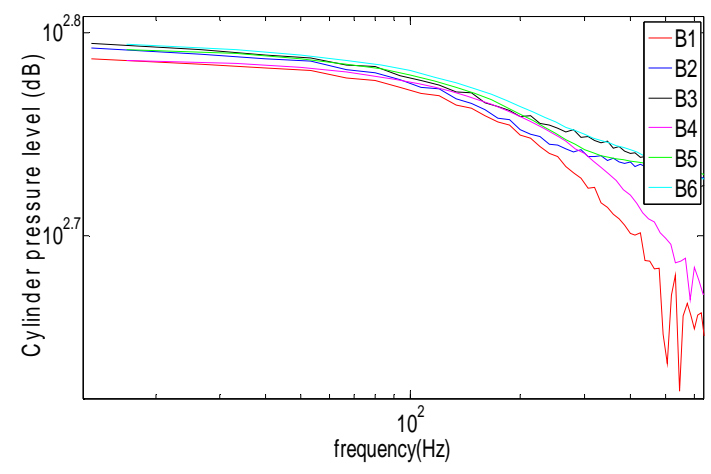

Figure 5-In Cylinder Pressure Levels

In order to investigate further,envelopes of noise signals was plotted as seen in figure no $5 \& 6$ using Hilbert transformations.These signals showed irregularity with peaks.Specialaly for higher load conditions these peaks had higher amplitute.

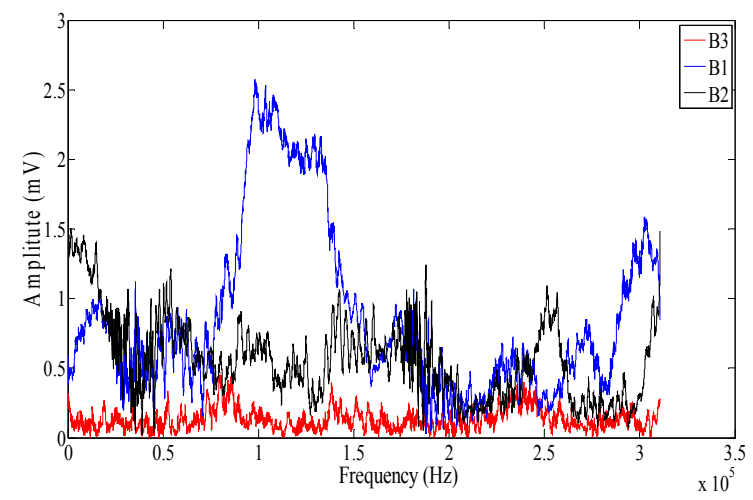

Figure 6-Envelope of Noise Emisions(1600RPM)

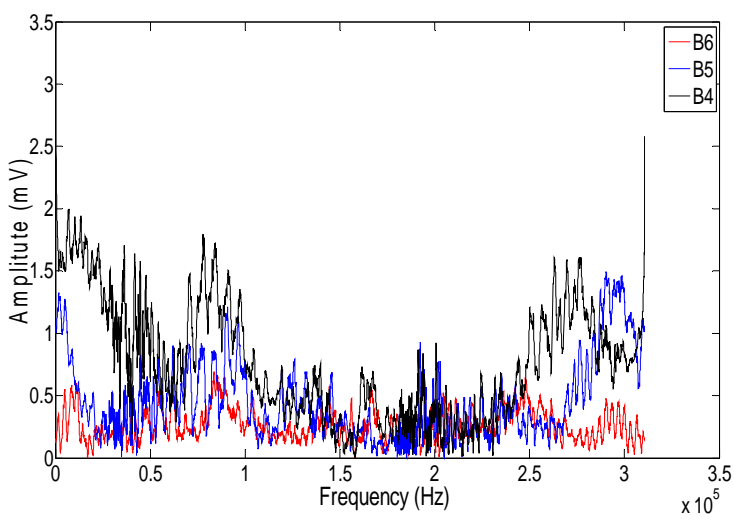

Figure 7-Envelope of Noise Emisions(2000RPM)

Noise emissions was found to be dependent upon the angle of fuel injections with an increase observed with angle of advance.Majority of peak values of signlas was found to be in medium and low frequency ranges.Noise signals at microphones come from various sources,hence the charecteristic of noise spectrum can reflects features of various noise sources.In order to understand contribution of various sources,coherent power spectrum is an important analysis tool.Input coherent power spectrum can be obtianed from the product of coherent function and input power spectrum. The coherence function $\mathrm{C}_{\mathrm{P}, \mathrm{n}}$ between in cylinder pressure and noise signals was computed to identify the frequency band in which two signals are strongely correlated.This function can be written mathematically as:

$$
C_{(\mathrm{p}, n)}(f)=\frac{P_{(\mathrm{p}, n)}^{2}(f)}{P_{(\mathrm{p}, \mathrm{p})}(f) P_{(n, n)}(\mathrm{f})}
$$

Where $P_{(\mathrm{p}, \mathrm{n})}$ is cross power spectral density of input signal(in cylinder pressure) and corressponding output signal(Noise).Coherence plots between cylinder pressures \& noise levels for test conditions was computed in order to isolate the effect of combustion process taking place in cylinders within a hamming window of length equal to $1 / 6^{\text {th }}$ of engine cycle. as seen from figure no 7-12.

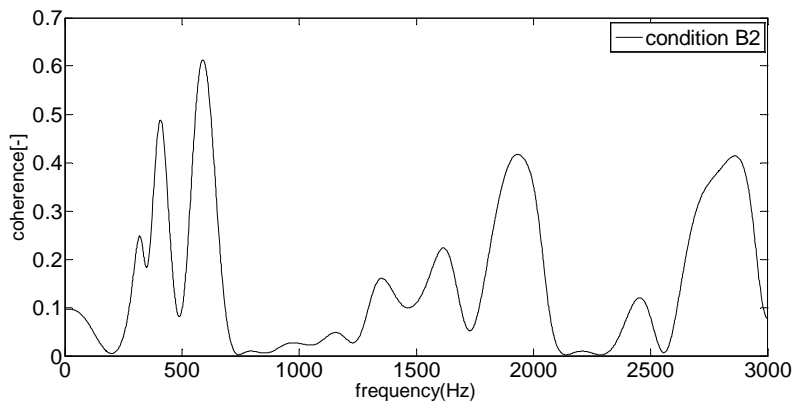

Figure 8-Coherence between cylinder presure and Noise Emissions(Case B2)

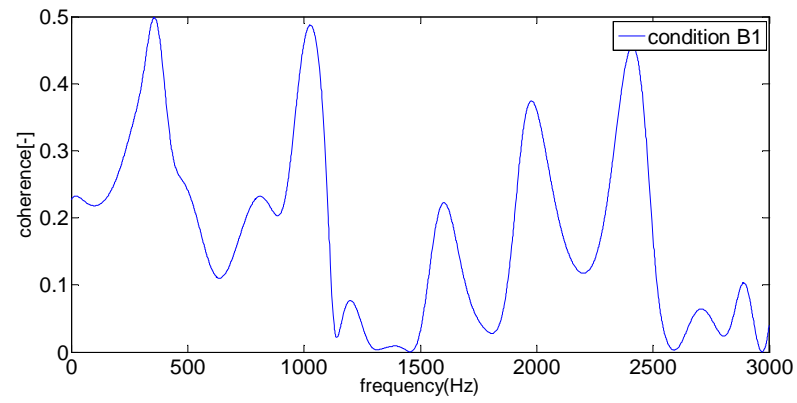

Figure 9-Coherence between cylinder presure and Noise Emissions(Case B1)

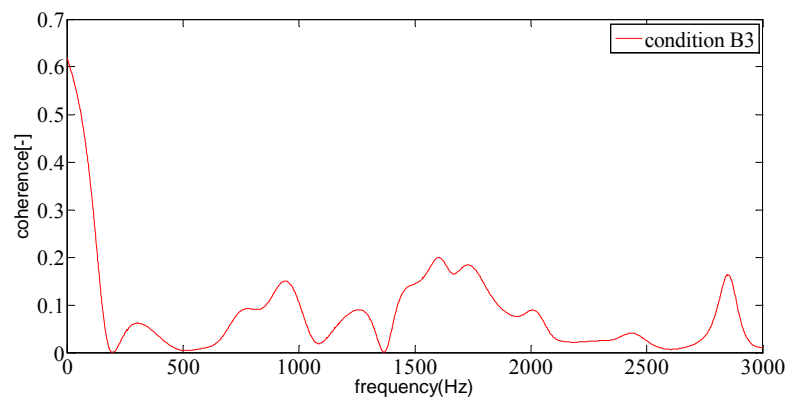

Figure 10-Coherence between cylinder presure and Noise Emissions(Case B3)

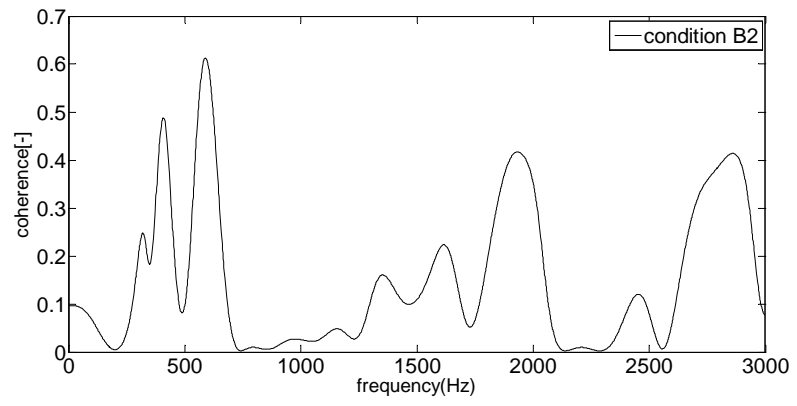

Figure 11-Coherence between cylinder presure and Noise Emissions(Case B6) 


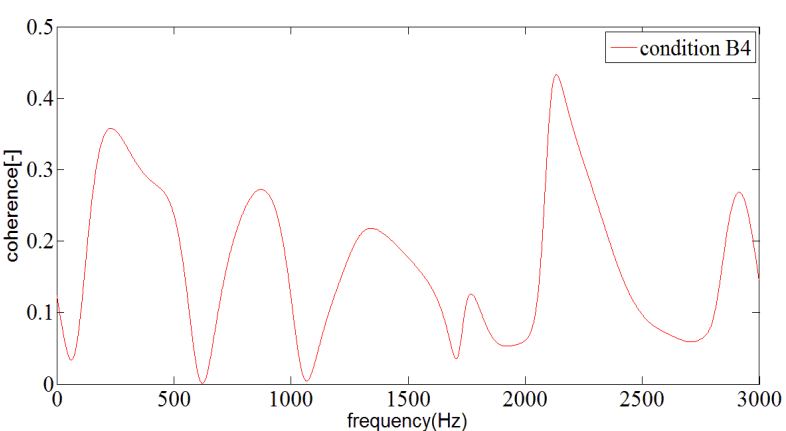

Figure 12-Coherence between cylinder presure and Noise Emissions(Case B4)

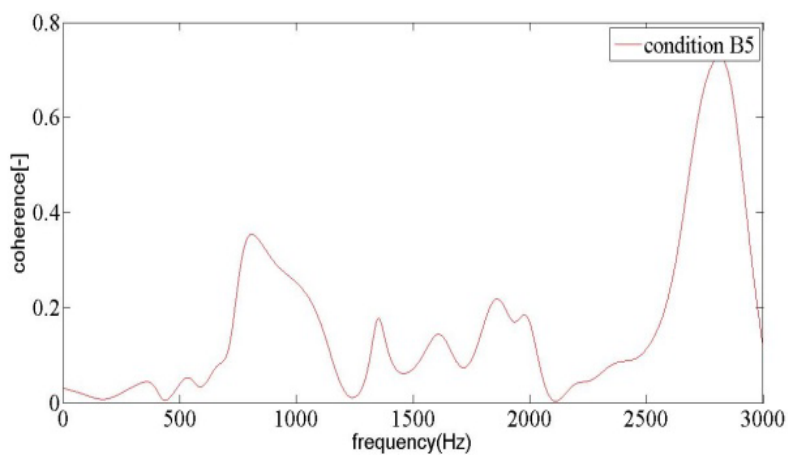

Figure 13-Coherence between cylinder presure and Noise Emissions(Case B5)

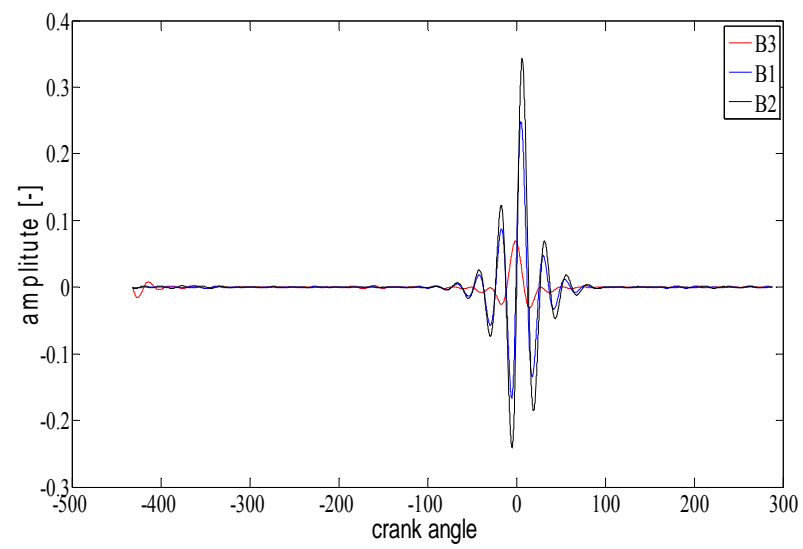

Figure14-Filtered Pressure signals(1600RPM)

In order to give an indication on how much uncertainity is there in the evaluation of the coherence function, a confidence level can be fixed.The choice of this level in practice lies between $90 \%-98 \%$. By fixing upper limit (a)as 98\%,a threshold value (TV)of 0.051 was obtained based on relationship based on window length(L) as :

$$
T V=1-(1-\mathrm{a} / 100)^{\frac{26}{L-1}}
$$

Values of coherence beliw this limit can be neglected as there is a lack of linear association between two signals.It can be seen that the coherence plots that traces have values well above the defined limits in some frequency ranges.In order to focus on combustion process, the attention must be turned towards selection of frequency band showing high amount of correlation between noise and cylinder pressure signals can be seen.For given test conditions this band was found to be $500-1000 \mathrm{~Hz}$. The noise and pressure signals were filtered in this frequency band to analyze the combustion process. Results can be seen in figures 1215.

There are clearly two peaks visible in the filtered pressure signals before TDC position of $0^{\circ}$ which corresponds to pre and main ignition events.Filtered noise signals also showed high amplitute near TDC which may be attributed to noise due to high piston slapping motion.

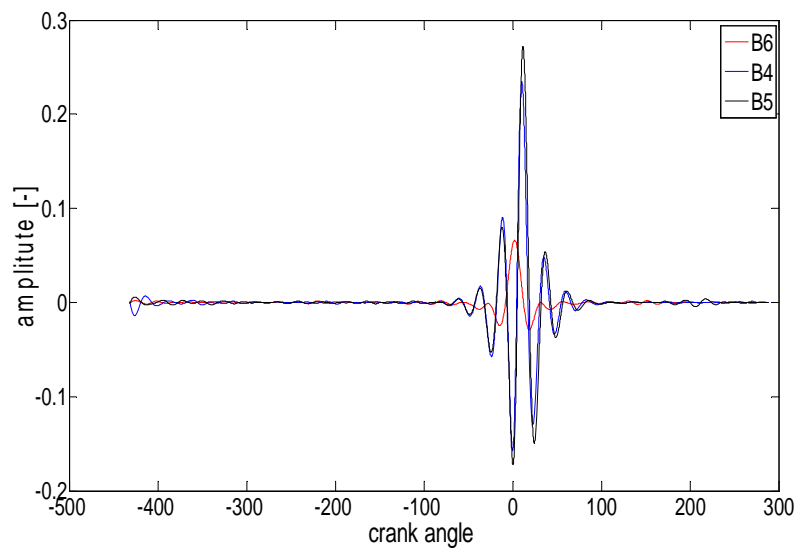

Figure15-Filtered Pressure signals(2000RPM)

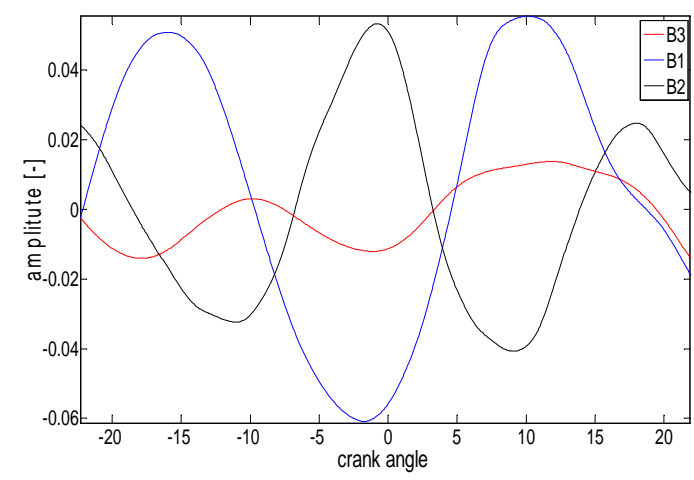

Figure16-Filtered Noise signals(1600RPM)

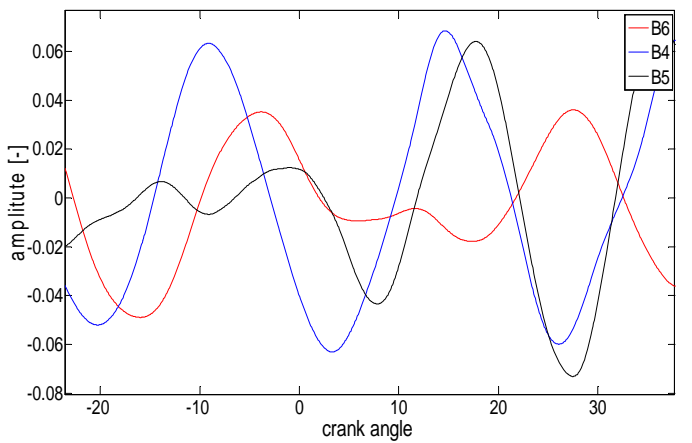

Figure17-Filtered Noise signals(2000RPM)

\section{CONCLUSION}

This work explores the use of non- intrusive method to study the diesel engines. The proposed methodology is based on acquisition of pressure and noise signals from engine by means of various sensors. In regular engine running conditions an automatic procedure to control performance may be based upon control of injection parameters using ECU unit. The signals acquired may be used to define a frequency band in which combustion process dominates. The data thus acquired may be used 
as a feed back to control injection parameters to control noise and vibrations emitted from engine.

\section{REFERENCES}

[1] Priede, T.: Relation between form of cylinderpressure diagram and noise in diesel engines, Proceedigs of Institute of Mechanical Engineers (A.D.) No. 1, Jan. 1960, pp. 63-77.

[2] Crocker, M., and Hamilton, J.: Modeling of diesel engine noise using coherence, SAE Technical Paper $790362,1979$.

[3] Goff, K.W.: The application of correlation techniques to source acoustical measurements, Journal of Acoustic Society of America, Vol 27, No 2, pp. 336-346, 1955.

[4] Seybert, A.F. and Crocker, M.J.: The use of coherence techniques to predict the effect of engine operating parameters on diesel engine noise, Journal of Manufacturing Science and Engineering No. 97, Vol. 4, pp. 1227-1233, 1975.

[5] Kumar, S. and Srivastava, N.S.: Investigation of noise due to structural vibrations using a crosscorrelation technique, Journal of Acoustic Society of America, Vol. 57, No 4, pp. 769-772, 1975.

[6] Wang, M.E.: The Application of Coherence Function Techniques for Noise Source Identification, Ph.D. Thesis, Purdue University, May 1978.

\section{NOMENCLATURE}

- $Q$ pre - Amount of fuel injected during preinjection Period ( $\mathrm{mm}^{3}$ per stoke)

- $\quad Q_{\text {main }}$ - Amount of fuel injected during maininjection Period ( $\mathrm{mm}^{3}$ per stoke)

- $\quad$ SOI pre -Angle of start of pre-injection period (degrees before Top Dead Center)

- SOI main - Angle of start of main-injection period (degrees before Top Dead Center)

- P rail - Injection Pressure of fuel inside cylinder

- $\quad$ BTDC-Before Top Dead Center

- $\quad$ FFT-Fast Fourier Transformations

\section{ПРИКАЗ АКУСТИКЕ ДИЗЕЛ МОТОРА}

\section{Sunny Narayan}

Бука коју емитују дизел мотори може се моделовати помоћу дијаграма кохерентности коришћењем једно-излазне, више-улазне методе. Извори буке код дизел мотора могу се одредити и упоређивати помоћу спектра буке код притиска у цилиндру пре и после елиминисања различитих извора буке у циљу одређивања њихових ефеката. Радови Придеа су допринели бољем разумевању елемената буке код дизел мотора [1]. Циљ овога рада јесте примена модела кохерентности у проучавању феномена акустике код дизел мотора. 